\title{
Educação e diversidade religiosa: onde está o conhecimento sobre a tradição religiosa africana na vivência da lei $10.639 / 03$ ? $^{1}$
}

\author{
Ariene Gomes de Olveira* \\ Allene de Carvalho Lage**
}

\begin{abstract}
Resumo
Este artigo tem como objetivo discutir a importância de um trabalho pedagógico que contemple a diversidade cultural religiosa nas escolas públicas a partir da experiência e/ou visão de sujeitos candomblecistas. A pesquisa foi realizada num terreiro de Candomblé de Nação Ketu em Caruaru-PE, por meio de entrevistas semiestruturadas, tendo como aporte teórico os estudos pós-coloniais e guiada pelo Método do Caso Alargado. Neste sentido, discutimos a prática pedagógica eurocêntrica presente na formação dos professores, diante da necessidade de se trabalhar com a cultura africana no âmbito escolar. Desta forma, encontramos a importância dos conhecimentos existentes no Candomblé, como fonte de saberes relacionados à cultura africana para o trabalho com a Lei 10.639/03 no âmbito escolar e também como alternativa para minimizar a intolerância religiosa presente contra esta religião na sociedade.
\end{abstract}

Palavras-Chave: Candomblé; Intolerância Religiosa; Educação étnico-racial)

\section{Education and religious diversity: where is the knowledge about the African religious tradition in the Law} 10.639/03?

\begin{abstract}
This article has the aim to discuss the importance for a pedagogical work that contemplates the religious cultural diversity in public schools from the experience and/or subject candomblecistas vision. The research was carried out in a yard of Candomblé Ketu nation in Caruaru-PE, through semi-structured interviews, having as theoretical support the post-colonial studies and guided by the Case Method Extended. In this sense, we discuss the Eurocentric pedagogical practice present in the training of teachers, given the need to work with African culture in schools. So, we found out the importance of the existing knowledge in the Candomble, as a source of African knowledge to work with Law 10,639/03 in the school and also as an alternative to minimize this religious intolerance against this religion in society.

Keywords: Candomblé; Religious intolerance; Ethnic-racial education.
\end{abstract}

\section{Introdução}

O presente artigo é parte integrante da dissertação de mestrado que teve sua conclusão em abril de 2014, onde foi pesquisado um Terreiro de Candomblé Ilê Axé Xangô Airà de Nação Ketu, na cidade de Caruaru - Pernambuco. Sendo assim, tem por finalidade discutir a importância de um trabalho pedagógico que contemple a diversidade cultural religiosa a partir da visão de pessoas que integram a religião do Candomblé, tanto as que estão em fase de formação escolar, como também as que já ultrapassaram esta etapa em suas vidas. Por meio das conversas informais e entrevistas semiestruturadas, contamos com o depoimento de seis candomblecistas, que ocupam cargo de destaque no terreiro sendo eles: Babalorixá, chefe do terreiro ou pai de santo; Yákekerê, cargo feminino, responsável pelo terreiro na ausência do pai ou mãe de santo; Ekedes de salão, cargo feminino que tem a responsabilidade de tomar conta das pessoas que estão em transe; Ogan Pegigan, cargo masculino responsável pela camarinha; Ogan Alabê, cargo masculino responsável pela música no terreiro.

Nesse sentido, buscamos a partir do

*Endereço eletrônico: arienegomes@ @otmail.com

***Endereço eletrônico: allenelage@ yahoo.com.br depoimento destas pessoas em confronto com a produção teórica na área, levantar reflexões acerca do Ensino de História e Cultura Africana no âmbito escolar, tendo como eixo norteador um trabalho pedagógico que possibilite conhecimentos sobre a religião do Candomblé e consequentemente respeito a esta opção religiosa.

Dentro desta perspectiva, os estudos póscoloniais concedem o entendimento de que esta tarefa não é fácil, pois a base científica dos cursos de formação dos professores ainda é colonial, com uma visão unilateral, onde apenas os saberes produzidos pelos povos brancos são credíveis dentro da sociedade. Desta forma, falar de religião africana, enquanto elemento integrante e norteador da tradição de muitos povos que foram responsáveis pela formação cultural brasileira, ainda é um entrave ao trabalho pedagógico que esteja comprometido com a diversidade cultural.

Como reação à exclusão social que o homem e a mulher negra e sua cultura vem passando no decorrer da história, o Movimento Negro em sua luta contra o racismo e por espaço social conquistou no âmbito educacional a sanção da Lei 10.639/03 para tratar do estudo da História e da Cultura Africana. Tal 
fato teve como objetivo o reconhecimento e a valorização dos povos africanos e de todo um conjunto de conhecimentos e tradições culturais que trouxeram consigo.

Em 2008, essa lei é modificada pela 11.645/08 que unifica o ensino da cultura africana, associado à cultura indígena, fato que se constitui numa perda de espaço que ainda estava em vias de conquista. Isto se associa ao fato que o ensino de base eurocêntrica que temos nas escolas, impede que se efetive um trabalho pedagógico que contemple tanto a cultura indígena, como a africana, abordando a temática de maneira folclorizada e descontextualizada.

\section{Metodologia}

Nas questões metodológicas, utilizamos a abordagem qualitativa para a investigação, por meio do estudo exploratório e explicativo. O nosso percurso analítico foi trilhado nos termos do Método do Caso Alargado, conforme definido por Boaventura de Sousa Santos (1983) e utilizado na pesquisa em que ele desenvolveu no Recife, tendo como objeto de estudo o caso da Favela Skylab em 1983. Tal método unifica a análise estrutural com a fenomenológica, onde os elementos que estruturam o caso são estudados para compreensão do todo, atrelados à análise da fala dos sujeitos que participam da pesquisa. Nessa direção esse autor diz:

Os dois tipos de análises não só são minimamente compativeis como se exigem reciprocamente. Por duas razões principais. Em primeiro lugar, os seres humanos mobilizam nas práticas sociais conhecimentos-à-mão que fazem parte dos stocks de sentidos acumulados na sua Lebenswelt (SANTOS, 1983, p.10).

Lage (2009, p.07) diz que o "Método do Caso Alargado é caracterizado por um estudo de caso convencional que tem alargada as suas implicações quando das suas conclusões". Ou seja, ele parte de um estudo de caso, que se apoia numa teoria para fazer a leitura da realidade, nos quais os resultados oferecerão possibilidades de compreensão de outros casos que estejam inseridos em contextos semelhantes.

\section{Estudos Pós-coloniais}

A formação da América Latina foi marcada pelo domínio europeu e surgiu a partir da invasão e exploração das terras dos povos indígenas, como também de sua força de trabalho. No entanto, esse processo de opressão amplia-se com a escravização dos povos africanos que foram arrancados de suas terras, através do tráfico de escravos, constituindo-se no maior sequestro da história mundial.

Wallerstein (1993, p.42) discute a questão do descobrimento da América como a imposição da subalternização, por parte dos colonizadores, movidos por interesses de exploração da força de trabalho dos povos colonizados, que foi a base para a criação da economia capitalista. Essa subalternização foi gerada tendo como parâmetro o modelo geocultural do grupo dominante, onde tudo que estava relacionado ao mundo dos dominados, não era digno de credibilidade, associado ao atraso e ao primitivismo.

Neste contexto, a ideia da formação deste continente está associada à subalternização desses povos, negação de sua condição epistêmica e exploração dos recursos naturais aqui existentes para a construção, enquanto potência europeia. Dessa maneira, a Europa se faz a partir da formação da América Latina, que por sua vez é uma criação da primeira devido às necessidades de sua própria constituição e expansão. Em relação à ideia de "invenção" da América, Mignolo (2007) nos diz: " "América' nunca fue um continente que hibiese que descobrir sino uma invención forjada durante el processo de la historia colonial europea y la consolidación de las ideas e instituciones occidentales" (MIGNOLO, 2007, p.28).

Mignolo (2007) também diz que a versão de "descobrimento", não foi relatada pelos povos que aqui habitavam e sim pelos europeus que dessas terras se apropriaram. Esta versão que foi contada por mais de quinhentos anos, só vai ser questionada a partir das consciências dos próprios explorados, a qual o autor denomina "consciência crioula de mundo" (MIGNOLO, 2007, p.28). Devido a essa consciência, a história oficial, que pertence ao mundo científico do colonizador, começa a ser questionada pelos povos colonizados, quebrando paradigmas no mundo acadêmico latino-americano. Com isso, abrem-se possibilidades para que os homens e mulheres subalternizados passem a falar de suas próprias experiências.

Por sua vez, Boaventura Santos (1993) diz que, em relação aos seres humanos todo descobrimento é um encobrimento quando não há um ato de reciprocidade, entre quem foi descoberto e o seu descobridor, conforme se vê na citação seguinte. Se a história da colonização calou a experiência existencial de homens e mulheres que na América existiam, o ato de descobrir foi um encobrimento da história e da identidade cultural dessas pessoas. Como diz Boaventura Santos (1993): 
Contudo, existe uma diferença radical entre descobrir uma coisa e descobrir o ser humano: descobrir um ser humano implica em reciprocidade. Quem descobre é descoberto. Se por qualquer razão esta reciprocidade é negada ou ocultada, o acto de descobrir, sem deixar de o ser, torna-se simultaneamente um acto de encobrir (SANTOS, 1993, p. 07).

Nesse sentido, a violência cometida aos povos escravizados vindos da África estendeu-se tanto em nível físico como também em nível simbólico, num ato de encobrimento, pois tiveram a sua história, os seus saberes e os valores culturais ocultados e descredibilizados pela ação do colonizador. A Europa não só impôs a sua cultura para os novos povos como também propagou uma imagem de civilização que adotava como padrão as suas referências culturais, enquanto que o outro, o diferente, era rebaixado a uma condição de selvageria. Dentro dessa realidade, a sociedade em formação passou a se distanciar dos valores desses povos acreditando que de fato eram inferiores, esforçando-se por assemelhar-se em todos os aspectos a cultura eurocêntrica e cristã, que tendo poder, difundia seus valores como superiores.

Ao estudar sobre esta desvalorização do modo de vida dos povos colonizados, Quijano (2010) voltou-se no primeiro momento para os aspectos da imposição do poder do homem branco em relação aos indígenas e negros, que foram subtraídos a força servil e escrava de trabalho para o enriquecimento do colonizador. Neste sentido, a cor da pele constituíase na marca da diferença entre quem deveria mandar e obedecer, emergindo a questão da raça e divisão racista do trabalho. Quijano (2010, p. 120) diz: "A cor da pele foi definida como marca "racial" diferencial mais significativa, por ser mais visível, entre os dominantes/superiores ou 'europeus', de um lado, e o conjunto dos dominados inferiores 'não europeus' do outro".

Ainda segundo Quijano (2005) a partir da supremacia europeia e, consequente, visão eurocêntrica de mundo, surge à questão da racionalidade que permanece até hoje, onde os conhecimentos europeus prevaleceram como padrão em relação aos dos outros povos. Neste sentido afirma: "a modernidade e a racionalidade foram imaginadas como experiências e produtos exclusivamente europeus" (QUIJANO, 2005, p.111).

No mundo europeu a razão humana prevalecia em relação à concepção do divino e todas as sociedades que a concepção do sagrado estava atrelada aos fenômenos da natureza eram consideradas primitivas e, por isso que precisavam se modernizar, render-se aos postulados científicos. Este foi um ponto importante para a afirmação da dominação do eurocentrismo, refletindo no que Lander (2005) vem discutir sobre a colonialidade do saber.

Os diferentes recursos históricos (evangelização, civilização, o fardo do homem branco, modernização, desenvolvimento, globalização) têm todos como sustento a concepção de que há um padrão civilizatório que é simultaneamente superior e normal. Afirmando o caráter universal dos conhecimentos científicos eurocêntricos abordou-se o estudo de todas as demais culturas e povos a partir da experiência moderna $e$ ocidental, contribuindo desta maneira para ocultar, negar, extirpar toda experiência e expressão cultural que não corresponda a esse dever que fundamenta as ciências sociais (LANDER, 2005. p. 14).

A partir desses critérios todas as civilizações que compartilham crenças diferenciadas do cristianismo, com práticas religiosas na qual a concepção do sagrado está relacionada aos fenômenos da natureza são descredibilizadas. As ideias iluministas, onde o homem, a racionalidade e a ciência dominam o mundo ocidental, tornam-se padrão para as demais culturas. Nessa direção Mignolo afirma que: "No mundo secularizado da ciência posterior ao Séc. XVIII, à opressão epistêmica era a nova face da opressão religiosa no mundo sagrado do Cristianismo durante os séculos XVI e XVII" (MIGNOLO, 2003, p. 668).

A colonialidade do poder acarretou a desvalorização do ser humano de acordo com a sua raça; a colonialidade do saber descredibilizou todo conhecimento que não fosse produzido pelo mundo europeu, impondo a sua universalização para as demais civilizações e como consequência dessas duas formas de dominação surgiu mais um tipo de colonialidade, que é a do ser. Esta foi responsável em produzir um sentimento de inferioridade nos povos colonizados em relação ao seu colonizador, refletindo no comportamento do homem e da mulher negra em querer tornar-se branco para ser aceito socialmente.

Ao analisar o "sentimento de não existência", que foi estudado por Frantz Fanon (1979), a colombiana Catherine Walsh (2008), aponta para mais um eixo da colonialidade que é a do ser. Esta faz com que os homens e mulheres que foram negados pelo processo histórico busquem nos padrões estabelecidos pelo colonizador a única 
condição possível e credível para o enquadramento social.

La colonialidad del ser, um tecer eje, es la que se ejerce por medio de la inferiorización, subalternizacion y la deshumanización: a lo que Frantz Fanon (2009) se refere como el trato de la "no existência". Apunta la relación entre razón-racionalidad y humanidade: los más humanos son los que forman parte de la racionalidade formal- la racionalidade médio-fin de Weber que es la racionalidad de la modernidad concebida a partir del individuo "civilizado" (WASH, 2008, p. 138).

Além destes três eixos da colonialidade poder, saber e ser existe a colonialidade da natureza que também é discutida por Walsh (2008). Esta se relaciona as forças espirituais presentes na terra, no fogo, na água e no ar, vivificadas pelas religiões indígenas e africanas e que são negadas pelo pensamento europeu. Não só ao que refere à racionalização, que leva ao domínio da natureza e de tudo o que ela produz para o fortalecimento econômico dos dominadores, como também em seu aspecto religioso por não se enquadrar aos dogmas dos padrões religiosos cristãos.

Al negar esta relación milenaria, espiritual e integral, explotar y controlar la naturaleza y resaltar el poder do individuo moderno civilizado (que aún se piensa com relación al blanco europeo o norteamericano) sobre el resto, como también los modelos de sociedad "moderna" y "racional" com sus raices europeo-americanas y cristianas, este eje de la colonialidad ha pretendido acabar com todo la base de vida de los pueblos ancestrales, tanto indígenas como afrodescendentes (WALSH, 2008, p. 139).

Desta forma, a sociedade e seus aparelhos ideológicos são conduzidos pelos quatro eixos da colonialidade e assim preserva os padrões estabelecidos pela Europa, ao considerar como primitivo e atrasado o conjunto de saberes que estão presentes no modo de vida dos povos sulbalternizados. Neste contexto, estão inseridos os educandos e educandas que pertencem às religiões afro-brasileiras, que trazem consigo experiências culturais diferenciadas e que são silenciados ao chegarem aos estabelecimentos de ensino.

\section{Vivência da Lei 10.639/03 no âmbito escolar}

A instituição escolar é um lugar consagrado para repassar os saberes científicos, hegemônicos e que descartou qualquer outra forma de visão de mundo que não fosse a do colonizador. Segundo Fanon (1979) tem contribuído historicamente para a manutenção do poder do colonizador, como um aparelho de repressão ideológica e de submissão dos povos colonizados aos padrões coloniais. Sobre esse ato de violência diz:

Nas colônias o interlocutor legal $e$ institucional do colonizado, o porta voz do colono e do regime de opressão é o gendarme ou o soldado. Nas sociedades do tipo capitalista, o ensino religioso ou leigo, a formação dos reflexos morais que são transmissiveis de pai para filho, a honestidade exemplar de operários condecorados ao cabo de cinquenta anos de bons e leais serviços, o amor estimulado da harmonia e da prudência, formas estéticas do respeito pela ordem estabelecida, criam em torno do explorado uma atmosfera de submissão e inibição que torna consideravelmente mais leve a tarefa da força da ordem (FANON, 1979, p. 28).

Neste sentido, os povos subalternizados vêm lutando por espaço dentro do contexto social com o objetivo de mostrar a sua importância histórica e pelo reconhecimento e valorização de sua cultura e de sua epistemologia. Cunha Jr. (2005) traz a importância das lutas empreendidas pelo Movimento Negro na conquista da referida Lei. Entretanto, ressalta que a luta pela liberdade e posteriormente por espaço social, sempre estiveram presentes no povo africano tanto no pós-abolição como no período de escravização. Nesse sentido ele diz:

A marca africana é indiscutivel na cultura brasileira. Mas estes povos africanos e afrodescendentes, nas suas epopeias de busca de liberdade e de igualdade social, realizaram eixos marcantes da história social do povo brasileiro. Empreenderam milhares de quilombos, de rebeliões, de instituições no combate ao escravismo criminoso. Tiveram imensa participação em todos os movimentos da história nacional. No pósabolição, a história de africanos e afrodescendentes se transcreve na organização de novos movimentos sociais, religiosos, culturais, entre os quais se destaca um atuante Movimento Negro (CUNHA JR, 2005, p. 251). 
$\mathrm{O}$ autor afirma que por mais de um século os movimentos negros lutaram para que a História da Cultura Africana fosse contemplada pelo ensino brasileiro e só em 2003, isto veio a acontecer.

Gomes (2010, p. 67) ao falar sobre o surgimento e aprovação da Lei. 10.639/03, que torna obrigatório o ensino da História da África e da Cultura Afro-Brasileira, também diz que a mesma é o resultado da luta do Movimento Negro em seu enfrentamento contra o racismo, preconceito e discriminação que as pessoas negras vêm sofrendo no decorrer da história do Brasil. "Mais do que uma iniciativa do Estado, essa lei deve ser compreendida como uma vitória das lutas históricas empreendidas pelo Movimento Negro brasileiro em prol da educação" (GOMES, 2010, p. 67).

O Estado, pressionado pelos movimentos sociais negros, conferiu à educação, o lugar e a tarefa de reconhecimento da importância histórica do homem e da mulher negra na formação social brasileira. Objetivando com isso, o ressarcimento desta dívida em relação às pessoas negras que foram usurpadas em sua condição humana no processo de escravização e na negação das condições necessárias para a vivência de sua cidadania, no pós-abolição até os dias atuais. Nesse sentido, Cunha Jr. (2005) diz:

Nesta formulação da necessidade de combate à desigualdade, a educação figura como uma das formas importantes de mudança de estrutura social dos afrodescendentes. Para se combater esta desigualdade, a educação precisa teorizar, realizar práticas efetivas e específicas que modifiquem concretamente a situação dos afro-descendentes (CUNHA JR, 2005, p. 252).

Esse resgate deve voltar-se também para que a sociedade brasileira reconheça como ponto de partida as várias culturas presentes na história do povo africano. Isto engloba as visões de mundo e saberes que os diferenciavam e as lutas que empreenderam na conquista da superação da escravização, como também a resistência que tiveram para vivenciar as manifestações de sua cultura e dentre as mais importantes, a sua religiosidade e que ainda hoje é tratada com falta de respeito e descrédito pela sociedade.

De acordo com as diretrizes curriculares, a educação das relações étnico-raciais traz exatamente a proposta pedagógica de reverter a imagem negativa que se formou em torno das populações não brancas de nosso país. A mesma visa superar atitudes eurocêntricas e etnocêntricas que se propagaram na história da formação da sociedade brasileira.
Todavia, isto se constitui numa tarefa árdua, pois significa modificar uma concepção de educação, baseada nos valores da cultura dominante, enquanto herança colonial.

Cunha Júnior (2005) discute essa questão, atrelada a uma visão de cultura, identidade e história, trazendo a interligação que existe entre as mesmas no contexto africano e sua fragmentação na visão ocidental de mundo. Contudo ressalta que essa fragmentação na realidade é ideológica, revertendose num mecanismo de dominação, pois ao se trabalhar a história africana com a visão eurocêntrica, nunca será dada de fato à importância que esses povos tiveram na formação brasileira. Nesse sentido, diz:

A educação transmite a cultura. Assim, ela reserva o direito de dizer o que é cultura. Cabe, antes de qualquer coisa, perguntarmos qual educação, para quem e para quê? A educação faz a seleção dos temas por um critério unicamente ideológico e político, mas se ampara nas ciências para justificar as escolhas (CUNHA JR, 2005, $p$. 255).

Concordamos com o autor sobre o papel ideológico condutor de qualquer ato educativo, que de fato compromete-se com um tipo de homem e de sociedade a qual se pretende formar. A base da educação é científica e, portanto, colonial nos termos de Lage (2008), isto significa dizer que visões de mundo que não estejam conforme a história contada pelo homem branco, por fazerem parte de outra história, não terá espaço na educação escolar.

Este modelo educacional, que subalternizou a imagem dos povos africanos, negando-lhes o direito de contar a sua própria história, teve por consequência a falta de respeito às diferenças, a anulação dos saberes oriundos desses povos, que findou em racismo, preconceito e discriminação. Reeducar a população não depende apenas da escola, esta ação pode acontecer em espaços escolares e não escolares, desde que haja políticas públicas voltadas para esses objetivos.

Analisando a discussão feita por Cunha Jr. (2005) sobre a unificação da identidade, cultura e história, constatamos que os terreiros se constituíram, a priori, num lugar de conservação e consagração das africanidades. As religiões de matrizes africanas possibilitaram a agregação do povo negro em torno de uma cultura ancestral que valorizava a sua história, sua cultura e identidade. Tal fato ia de encontro à cultura hegemônica que divulgava a padronização de seus valores para uma melhor forma de dominação. Por isso, as religiões de 
matrizes africanas deveriam ser perseguidas pelo racismo ideológico em busca de sua desestruturação.

Os terreiros são fontes de saberes, sendo assim, constituem-se num acervo de pesquisa para um trabalho voltado para a educação étnico-racial. Isto consiste em fornecer informações sobre a história dessas religiões e de todo um legado de tradições relacionadas ao respeito a todos os aspectos da natureza, relação que o homem moderno/capitalista/ eurocêntrico esqueceu. Sobre a importância dos saberes existentes nos terreiros de Candomblé, Botelho (2005) diz:

Avalio ser importante inaugurar saberes sobre a cultura afro-brasileira a partir do desvelar e do desvendar das culturas presentes nos candomblés, desprezadas $e$ desvalorizadas, quando não simplesmente desconhecidas pela educação formal e por seus professores, mas de grande importância para uma pedagogia multirracial que permita uma real inclusão educacional (BOTELHO, 2005, p.48).

Concordamos com a avaliação realizada pela autora e acreditamos que os saberes do Candomblé deveriam ser trabalhados na escola como elemento da cultura africana. Este trabalho seria pertinente, pois abriria espaço para que a vivência dessa cultura não fique restrita a datas folclóricas, que em nada contribui para a valorização e reconhecimento social da cultura negra.

Todavia, para que este trabalho aconteça nas escolas se faz necessário investir na formação dos professores e estes ao terem conhecimentos sobre as culturas que foram subalternizadas na colonização, passam a ter um olhar de valorização sobre a experiência dos povos que tiveram os seus saberes descredibilizados. Munanga (2005) contempla essa discussão ao dizer:

No entanto, alguns professores, por falta de preparo ou por preconceitos neles introjetados, não sabem lançar mão das situações flagrantes de discriminação no espaço escolar e na sala como momentos pedagógicos privilegiados para discutir a diversidade e conscientizar seus alunos sobre a importância e a riqueza que ela traz à nossa cultura e a nossa identidade nacional (MUNANGA, 2005, p. 15).

A abertura de espaço para o conhecimento sobre a tradição africana presente no Candomblé oportuniza que se tenha uma visão diferenciada da que foi construída pelo discurso colonial em nossa sociedade, que deturpou e demonizou as religiões afro-brasileiras. Com esta atitude, a educação e seus agentes oportunizarão o respeito e a valorização destas religiões, bem como a opção religiosa de seus praticantes.

\section{Educação e Candomblé}

Um trabalho nas escolas voltado para a educação étnico-racial deve contemplar os conhecimentos que estão relacionados à diversidade étnica brasileira e suas respectivas culturas, promovendo um espaço de trocas culturais para que haja reconhecimento e valorização da cultura do outro. Nesse sentido, Walsh (2008) afirma:

De manera aún más amplia, proponho la interculturalidade crítica como herramenta pedagógica[...] hacen dialogar las diferencias en un marco de legitimidade, dignidade, igualdad, equidade y respeto, sino que también a la vez alimentan lá creación de modos "outros" de pensar, de ser, de aprender, enseñar, sonhar, vivir que cruzan fronteras (WALSH, 2008, p. 139).

Dentro desta perspectiva, os sujeitos com os quais dialogamos gostariam que a escola abrisse espaço para um diálogo intercultural que permeasse a discussão sobre o Candomblé e outras religiões. Eles acreditam que seja um caminho para que houvesse respeito às diferenças étnico-raciais e consequentemente religiosas.

Os povos de terreiro clamam pelo direito de exercerem a sua religião, livres da intolerância e depositam na escola a esperança de uma formação étnico-racial com respeito à cultura africana. Não estamos dizendo com isso que a escola se transformaria num espaço de vivência da religião africana, não propomos isso e nem tampouco os povos de terreiro. Entretanto queremos que a escola pública oportunize um diálogo que contemple a diversidade religiosa, que aborde a história das variadas religiões e dentre elas o Candomblé, pois acreditamos que o conhecimento supere a ignorância, em decorrência o preconceito e fomente atitudes de respeito.

No sentido de aprofundar essa discussão fizemos a seguinte questão: Que trabalho a escola pública poderia fazer para diminuir o preconceito em relação ao Candomblé? Logo, esses sujeitos nos oferecem sugestões para um trabalho que aponta para o que pede a Lei. 10.639/03, mesmo não sabendo sobre a sua existência, pois a maioria deles está afastada do contexto escolar. Sendo assim, são movidos pelo desejo que a história de sua religião, 
bem como as tradições que a envolve sejam reconhecidas dentro da sociedade por meio da educação escolar, como forma de minimizar o preconceito e a discriminação.

A resposta do Babalorixá aponta para um trabalho escolar, que oportunize o conhecimento sobre várias culturas e as diferenças religiosas ao dizer:

[...] tornar conhecido aquilo que não se conhece, se a escola pudesse hoje de uma forma leve adentrar no conhecimento religioso, qualquer uma que seja a religião. Trazendo o que de bom existiria em cada uma, essa intolerância seria tendenciosa a diminuir, não vou dizer que não existiria, mas diminuiria bastante. Então seria fazer o quê? Fazer estudos não só sobre o Candomblé, mas de outras que nós não conhecemos (BABALORIXÁ, IVAN. Diário de Campo: 18-09-2013).

Estabelecendo uma ponte entre o pensamento do Babalorixá e de Catarine Walsh (2005), constatamos uma comunicação entre ambos, pois a sugestão do Babalorixá volta-se para um trabalho na escola que contemple um diálogo intercultural entre as religiões. Quando esse líder religioso reflete que "Trazendo o que de bom existiria em cada uma, essa intolerância seria tendenciosa a diminuir", está falando no mesmo sentido de Walsh ao dizer que as diferenças deveriam dialogar num marco de legitimidade, dignidade, equidade e respeito.

Como alternativa para um trabalho na escola que contemple a tradição ancestral africana como forma de valorização e afirmação da identidade negra, Botelho (2005) traz a experiência dos Candomblés. O trabalho com a história do Candomblé mostrará aos educandos e educandas de todas as etnias a importância dessa religião como ponto de resistência. Nesse sentido, Botelho (2005) diz:

Lembremos que os candomblés- espaço, por excelência, dos orixás- serviram e servem para a preservação da herança cultural $e$ religiosa africana, sempre atuantes na luta do povo negro, resistindo à opressão, à dominação e a exclusão buscando um espaço de valorização da particularidade negra no patrimônio cultural brasileiro (BOTELHO, 2005, p. 45).

O Ogan Pegigan Robson da mesma forma que o Babalorixá também propõe um trabalho que contemple a diversidade cultural na escola pública, especificamente na aula de educação religiosa ao dizer: "Então essa educação religiosa podia ser uma coisa de religião afro também, podia falar de todos os segmentos da religião" (OGAN PEGIGAN ROBSON). Contudo, ele caminha na mesma direção que o pensamento de Botelho quando sugere que a educação escolar deveria contemplar o Candomblé, na medida em que essa religião aborda a questão das raízes africanas presentes na mesma. Ao dizer:

Mas, quando você parte para o Candomblé,
você parte para religião de raízes africanas,
quando você começa a ver os mitos, começa
a escutar as lendas, ver aquelas baianas, as
comidas que já fazem parte do dia a dia da
gente! (OGAN PEGIGAN, Robson. Diário
de Campo: 18-09-2013).

O Ogan Robson ao falar sobre os mitos, indumentárias e comidas que está na religião, está nos alertando para a tradição africana que se faz presente no Candomblé, nos oferecendo uma alternativa de trabalho com a História e Cultura Africana nas escolas. Nesse sentido, mais uma vez, seu pensamento é respaldado pelo de Botelho (2005, p. 48) ao dizer: "Avalio ser importante inaugurar saberes sobre a cultura afro-brasileira a partir do desvelar e do desvendar das culturas presentes nos candomblés".

Principalmente quando a autora ressalta o esquecimento da cultura africana pela imposição da cultura ocidental que faz com que a escola não valorize a tradição ancestral que está presente nessa religião ao dizer: "desprezadas e desvalorizadas, quando não simplesmente desconhecidas pela educação formal e por seus professores, mas de grande importância para uma pedagogia multirracial que permita uma real inclusão educacional" (BOTELHO, 2005, p.48).

O pensamento de Botelho (2005) também é contemplado pelo depoimento da Ekede Janine quando diz: "Falar mais de nossa religião. E isso é coisa que não fazem que não tem!" (EKEDE, JANINE). Nessa afirmação está o pedido para que a escola pública trabalhe com todas as religiões, contemplando uma "pedagogia multirracial" como diz Botelho. A Ekede complementa a sua afirmação dizendo: "Tem a matéria de religião que também falam na religião que é obrigado a ele falar de todas as religiões, mas eles não cumprem" (EKEDE, JANINE. Diário de Campo: 12-09-2013). Seu pensamento agora denuncia os professores que não cumprem com um conteúdo que abranja conhecimentos referentes a todas as religiões e que saiam da visão ocidentalizada, que insiste em 
"desprezar" e "desvalorizar" as religiões de matrizes africanas como afirmou Botelho.

O desprezo e desvalorização da religião africana são heranças coloniais, que levam a um patamar de discussão de maior complexidade que é a demonização da religião e sua perseguição dentro da escola pública. Desta forma, só o diálogo permeado por uma educação multirracial (BOTELHO, 2005) e intercultural (WALSH, 2005), seria uma alternativa possível para a minimização do preconceito e da descriminação.

A Ekede Vitória também aponta para a importância do conhecimento sobre o Candomblé nas escolas públicas ao dizer: "Deveria aprender na escola a história de como o Candomblé chegou ao Brasil e de como é cultuado, que o povo fala que a gente cultua o Diabo. Não! A gente cultua os Orixás, isso que deveria ser mostrado nos colégios" (EKEDE, VITÓRIA. Diário de Campo: 05-09-2013).

Desta forma, demonstra acreditar que o conhecimento sobre a história da religião, modificaria essa situação de opressão, pois espera que a abordagem dos aspectos relacionados à cultura africana que está presente dentro do Candomblé consiga reverter à imagem negativa construída pelo colonizador. $\mathrm{O}$ trabalho que reivindica falar sobre a história do Candomblé, mostraria a religião não apenas como espaço religioso, mas sua contribuição para a educação étnico-racial ao propiciar a afirmação da cultura negra, na medida em que se constitui como um lugar de resistência durante toda uma história de opressão colonial.

Percebemos a importância de um trabalho que oportunize o conhecimento e a valorização da cultura africana que foi invisibilizada pela imposição cultural hegemônica ocidental. Contudo, para que haja espaço na escola pública que abarque essas discussões se faz necessário trabalhar a questão do preconceito e da discriminação através da formação dos professores aos termos de Munanga (2005, p. 15) para que ultrapassem a visão monocultural eurocêntrica.

A necessidade da formação dos professores também foi um ponto contemplado na fala da Yákekerê Janaína, ao analisar o desrespeito que existe nos professores e professoras em relação ao Candomblé, a partir da realidade que suas filhas enfrentaram na escola pública, quando foram confirmadas Ekedes. Nesse sentido, diz:

Educar primeiro os professores, educar professores e todo, como eu posso te falar... Todas as pessoas que regem a escola, como supervisor, diretora até a faxineira, cozinheira, teriam que ser funcionários mais educados, não pessoas que por que tem uma religião acham que tem que impor, entendeu? Então para educar os alunos, tem que educar primeiro os professores (YÁKEKERÊ, JANAÍNA. Diário de Campo: 19-09-2013).

Munanga (2005, p. 15) ao analisar a formação do professor como "falta de preparo ou por preconceitos neles introjetados", contempla a reflexão que a Yákekerê faz sobre educar toda a equipe da Escola Pública. Mais adiante quando ela diz que "teriam que ser funcionários mais educados, não pessoas que porque tem uma religião acham que tem que impor", pede que as atitudes de discriminação sejam banidas da escola pública para que se possa haver um trabalho de respeito a todas as culturas. Esse ponto é contemplado por Munanga, no trecho de seu pensamento em que ele reflete sobre os momentos pedagógicos que são desprezados, ao dizer: "[...] não sabem lançar mão das situações flagrantes de discriminação", isto está relacionado à falta de preparo dos professores como diz a Yákekerê. "Os preconceitos neles introjetados" (MUNANGA, 2005 , p. 15), leva-os a não perceber as situações que ocorrem no espaço escolar [...] como momento pedagógico privilegiado para discutir a diversidade e conscientizar seus alunos sobre a importância e a riqueza que ela traz à nossa cultura e a nossa identidade nacional (MUNANGA, 2005, p. 15).

Como forma de contribuir com o trabalho dos professores em sala de aula Petrovich e Machado (2004) nos trazem a importância do Candomblé como um espaço que tem uma filosofia de vida relacionada aos saberes ancestrais, nesse sentido nos diz: "Significa dar atenção especial a educação de um "povo" que mantém todo um saber filosófico milenar, ligando sempre ao passado pela memória coletiva ancestral" (PETROVICH, MACHADO, 2004, p. 14).

Nesse sentido, o Ogan Alabê Flávio nos diz "Em primeiro lugar eu acho que nós do Candomblé tínhamos que ter um espaço, um museu, por exemplo, falando de nossos anciões [...]". Seu pensamento traz a questão dos saberes ancestrais discutidos por Petrovich e Machado (2004), da importância de revivê-los na memória coletiva, não só dos candomblecistas, como também de todos os que fazem parte da sociedade. Desta forma, tanto o Ogan como os autores analisam a importância do conhecimento ancestral que se mantém na tradição da religião através das pessoas mais velhas, que o repassam para as novas gerações. O Ogan traz no complemento de sua fala a importância do Candomblé como um espaço de produção de conhecimento para os educandos e educandas presentes nas escolas públicas ao dizer: “[...] para os 
alunos dos colégios poderem ver, vir estudar, saber o que é, o que não é e eles aprenderem e porque não dizer, também participarem de um xirê para saberem como é".

A análise realizada do depoimento dos sujeitos aponta para vários elementos que se encontra presente na religião que poderia ser aproveitado na educação escolar, numa perspectiva étnico-racial. No terreiro está a tradição africana que resistiu através dos tempos e que reforçam a identidade negra que é apagada pela escola, enquanto, espaço ideológico de preservação da cultura branca.

\section{Considerações Finais}

$\mathrm{O}$ aporte teórico que conduziu a nossa pesquisa e os sujeitos com os quais dialogamos, apontam para a necessidade de transformação da educação pública, na perspectiva de respeito à diversidade religiosa. Neste sentido, afirmam que o trabalho pedagógico deve ter como base o diálogo intercultural, onde a escola deve promover trocas entre os conhecimentos existentes em diversas religiões através da história das religiões. Assim, o preconceito seria diminuído em relação às religiões não hegemônicas, promovendo uma educação voltada para a igualdade racial.

Desta forma, enquanto o Candomblé e outras religiões não cristãs continuarem invisíveis para escola pública não haverá espaço para uma vivência multirracial. Então uma educação para a igualdade racial deve comprometer-se em promover conhecimentos que desmistifiquem a diabolização existente em relação às religiões afro-brasileiras.

Contudo, para que a escola possa abrir-se à vivência intercultural e multirracial com reconhecimento, respeito e, sobretudo valorização das diferenças é imprescindível que se faça um investimento na formação dos professores, visto que a formação de base eurocêntrica limita a visão dos mesmos levando-os ao etnocentrismo e preconceito.

A educação nos terreiros é um campo fértil para que seja explorada a História e a Cultura Africana, pois esta religião contribuiu para que o conhecimento baseado na tradição ancestral se mantivesse presente até a atualidade, resistindo ao processo de repressão cultural hegemônico. Então, se os professores rompessem com as barreiras do preconceito por meio de uma formação não eurocêntrica, possibilitaria à aprendizagem de conteúdos inerentes a cultura africana, presentes nos Candomblés, que foram sufocados pela cultura ocidental.

A contribuição dos sujeitos candomblecistas para a educação pública, na perspectiva da educação étnico-racial, é a de que o Candomblé se distancia dos valores hegemônicos e reafirma através de seus processos educacionais a tradição da sociedade africana. No momento em que os professores das escolas públicas, por meio de uma formação não hegemônica, trabalharem pedagogicamente os conhecimentos dessa cultura milenar presente na religião estarão exercendo uma docência intercultural de caráter multirracial e promotora de uma educação étnico-racial.

As Escolas Públicas, enquanto laicas, deveriam ser pautadas na educação das relações étnico-raciais, onde a educação intercultural e multirracial seria o eixo de uma pedagogia democrática, onde os educandos(as) pudessem dialogar sobre os diversos conhecimentos históricos presentes nas religiões que orientam o povo brasileiro. Numa experiência onde o respeito e a valorização da vivência do universo cultural do outro se constituiriam numa base de aprendizagem democrática. Assim, os saberes milenares presentes nas religiões de matrizes africanas tornar-se-iam uma fonte de pesquisa para o trabalho com a História e a Cultura Africana e afro-brasileira. Entretanto, a vivência desta possibilidade de educação democrática, implica na formação dos professores numa base multicultural e não eurocêntrica.

\section{Nota}

1 Pesquisa financiada com o apoio da FACEPE.

\section{Referências}

BOTELHO. D. M. Educação e Orixás: Processos educativos no Ilê Axé Iya Mi Agba. 2005. 126 f. Tese (Doutorado em Educação). Universidade de São Paulo, São Paulo, 2005.

BRASIL (1996). Lei $n^{\circ} 9.394$ de 20 de dezembro de 1996. Lei de Diretrizes e Bases da Educação Nacional. Brasília: Ministério da Educação.

FANON, F. Os condenados da terra. 2ed. Rio de Janeiro: Civilização Brasileira. 1979.

MIGNOLO, W. La idea de América Latina: la herida colonial e la opción decolonial. Barcelona: Gedisa, 2007.

MUNANGA, K. Superando o racismo na escola. 2. ed. Brasília: MEC, Secretaria de Educação Continuada, Alfabetização e Diversidade, 2005.

GOMES. N. A questão racial na escola: desafios 
colocados pela implementação da Lei.10.639/03. In: Multiculturalismo: Diferenças Culturais e Práticas Pedagógicas. 4. ed. Petrópolis: Vozes, 2010, p. 6789.

Educação e Relações Raciais: Refletindo sobre Algumas Estratégias de Atuação. In: MUNANGA, Kabengele. Superando o racismo na escola. 2. ed. Brasília: MEC, Secretaria de Educação Continuada, Alfabetização e Diversidade, 2005, p. 143-154.

JR, H. Nós, afrodescendentes: História africana e afrodescendentes na cultura brasileira. In: ROMÃO, Jeruse (Org.). História da Educação do Negro e outras histórias. Secretaria de Educação Continuada, Alfabetização e Diversidade. - Brasília: Ministério da Educação, Secretaria de Educação Continuada, Alfabetização e Diversidade. 2005.

LANDER, E. Ciências Sociais: Saberes coloniais e eurocêntricos. In: LANDER, Edgardo (org). La colonialidade do saber: eurocentrismo e ciências sociais. Perspectivas latino-americanas. Buenos Aires: CLASCO Y UNESCO, 2005 p. 21-54.

LAGE, A. C. Da subversão dos lugares convencionais de produção do conhecimento à epistemologia de fronteira: Que metodologias podemos construir com os movimentos sociais? $E$ cadernos CES (Online), v. 2, p. 1-19, 2008.

Orientações epistemológicas para pesquisa qualitativa em educação e movimentos sociais. In: Anais do IV Colóquio Internacional de Políticas e Práticas Curriculares: Diferenças nas Políticas de Currículo. João Pessoa: UFPB, 2009.

PETROVICH, C. MACHADO, V. Ire Ayó. Mitos afro-brasileiros. Salvador: EDUFBA, 2004.

QUIJANO, A. Colonialidade do Poder, Eurocentrismo e América Latina. In: LANDER, E. (Org.). A Colonialidade do Saber: eurocentrismo e Ciências Sociais. 3. ed. Buenos Aires: CLACSO, 2005, p. 227-278.

SANTOS, B. de S. Os Conflitos Urbanos no Recife: O Caso do "Skylab". In: Revista Crítica, no 11, maio, p. 9-59. Coimbra: CES, 1983.

Descobrimentos e Encobrimentos. In: Revista Crítica de Ciências Sociais, no 38, dezembro, p. 510. Coimbra: CES, 1993.

WALLERSTEIN, Immanuel. Encontros: $1492 \mathrm{e}$ Depois; Descobertas; 1992 e Antes. In. SANTOS Boaventura (Org.). Revista Crítica de Ciências Sociais, $\mathrm{n}^{\mathrm{o}}$ 38, dezembro, p. 41-55. Coimbra: CES, 1993.

WALSH, C. Interculturalidad, Plurinacionalidad y Decolonialidad: Las Insurgencias PolíticoEpistémicas de Refundar el Estado. In. Revista Tabula Rasa. Bogotá - Colombia, n. 9: 131-152, julio-diciembre 2008.

\section{Sobre as autoras}

Ariene Gomes de Oliveira é mestra em Educação pela Universidade Federal de Pernambuco- CAA (2014), professora do Curso de Pedagogia da Faculdade Escritor Osman Lins e Professora da Secretaria de Educação do Estado de Pernambuco.

Allene Lage é doutora em Sociologia pela Universidade de Coimbra (2006), Pós-doutora em Educação pela UFRGS (2012) e Pós-doutora em Direitos Humanos pela UFPE (2016). Professora Associada da UFPE e Professora PPGEDU/UFPE e PPGDH/UFPE.

Recebido em junho de 2015. Aprovado em maio de 2016. 